\title{
Propojení přírodovědného a environmentálního vzdělávání
}

O čem se píše $v$ časopise Science? Volný překlad textu:

Wals, Arjen E. J., Michael Brody, Justin Dillon, Robert B. Stevenson (2014).

Convergence Between Science and Environmental Education. Science, 344(6184), 583-584. Dostupné z http://www.sciencemag.org/content/344/6184/583.short

Publikováno se souhlasem časopisu Science

Publikováno v Envigogika 10 (2) - Recenze/ Reviews

Publikováno/Published 21. 1. 2015

DOI: $\underline{10.14712 / 18023061.458}$

\section{Abstrakt}

O čem se píše v časopise Science? Parafráze textu: Wals, Arjen E. J., Michael Brody, Justin Dillon, Robert B. Stevenson (2014). Convergence Between Science and Environmental Education. Science, 344(6184), 583-584. DOI: 10.1126/science.1250515

\section{Klíčová slova}

environmentální vzdělávání; prrírodovědné vzdělávání; občanská věda

\begin{abstract}
What is written about in Science journal? A paraphrase of the article: Wals, Arjen E. J., Michael Brody, Justin Dillon, Robert B. Stevenson (2014). Convergence Between Science and Environmental Education. Science, 344(6184), 583-584. DOI:10.1126/science.1250515
\end{abstract}

\section{Key words}

Environmental education; science education, civic science 
Závažné problémy současné doby, například změna klimatu, nedostatek potravin, podvýživa nebo snižování biodiverzity, jsou častým tématem diskusí ve vědě i ve společnosti; ty však vyžadují celostní pohled na zmiňované problémy (Nisbet, 2009). Získatpozornost pro tyto tzv. výzvy udržitelnosti by ovšem měli především environmentální pedagogové a pedagogové prírodních věd. Tady však bohužel dochází $\mathrm{k}$ čím dál většímu vzdalování mezi pedagogikou přírodních věd (PP), která se zaměřuje především na výuku znalostí a dovedností, a environmentálních pedagogikou (EP), jež klade důraz na hodnoty a změny chování. Vztah mezi PP a EP bývá charakterizován jako "odměřený, soutěživý, vztah predátora a kořisti, vztah hostitele a parazita" (Gough, 2002). Autoři textu Convergence Between Science and Environmental Education, který vyšel v časopise Science a z něhož zde představujeme podstatnou část, se zabývali možností postupného sbližování $P P$ a $E P$, jehož výsledkem by mohlo být větší zapojení veřejnosti do řešení základních socioekologických výzev.

Od konce 2. světové války je vzdělávání $v$ prírodních vědách motivováno potřebou vytvořit dostatečně silnou vědeckou a technickou základnu pro urychlení inovací a posílení konkurenceschopnosti. Environmentální pedagogika se objevila až na začátku 60. let 20. století, a to jako reakce na naléhavou environmentální krizi té doby. Cílem EP tak bylo rozvíjet ekologickou a environmentální gramotnost nezbytnou pro pochopení sociopolitických, hodnotově orientovaných, místně ukotvených a emocionálních souvislostí, ze kterých environmentální problémy vzešly, a v rámci nichž jsou také řešitelné. Rozdíl mezi PP a ranou EP spočival $v$ jejich zaměření: zatímco cílem PP bylo např́klad naučit studenty monitorovat kvalitu vody, zjištóvat její znečištění a pochopit technologie, které toto znečištění omezí, EP se zabývala zkoumáním příčin a modelů chování, které ke znečištění vedly, nebo hledala postupy, které by k zájmu o vyčištění řeky přivedly místní komunitu, představitele obce a podniky.

Oby přístupy, EP a PP, by ovšem měly ke komplexním environmentálním problémům i k související výchově kompetentních občanů, kteří by dokázali na současné výzvy přiměřeně reagovat, přistupovat společně $a v$ úzké spolupráci. $K$ takové vyzrálé symbióze poukazují trendy popisované $v$ právě vycházející Mezinárodní príručce pro výzkum $v$ environmentálním vzdělávání (International Handbook of Research on Environmental Education) (Stevenson et al., 2013). Jak se zde uvádí, vzdělávání by mohlo lépe reagovat na globální environmentální problémy, pokud se takové vazby mezi EP a PP vytvoří, ale také například jestliže se bude věnovat pozornost tzv. občanské vědě podporované využitím informačních a komunikačních technologií (ICT).

\section{Výzkum v environmentální výchově}

Většina výzkumů v oblasti environmentální výchovy (prováděných především ve Spojených státech) se zpočátku zaměřovala zejména na účinnost vzdělávacích aktivit ve vztahu ke změně environmentálně relevantního chování jedince. Tento př́stup ovšem podpořil houževnatě se udržující, nicméně nepodložené přesvědčení o existenci jednoduché lineární závislosti mezi znalostmi, hodnotami, postoji a environmentálním chováním. Výzkumy, zejména $v$ oblasti sociální psychologie, však ukázaly, že tento předpoklad př́liš zjednodušuje možnosti ovlivňování lidského jednání (Kollmuss, Agyeman, 2002).

$\checkmark$ dnešní době se většina výzkumů $v$ oblasti environmentálního vzdělávání zaměřuje na okolnosti vzdělávacího procesu a zabývá se přístupy, které by občanům všech generací (i) pomáhaly se orientovat $v$ nastalých environmentálních situacích a myslet pritom samostatně, kriticky, kreativně a s ohledem na hodnoty; (ii) umožňovaly jim se v těchto 
situacích informovaně rozhodovat; a (iii) podporovaly by schopnost a ochotu jednat individuálně či kolektivně způsoby, které zlepšují stav životního prostředí.

Tento nový cíl klade menší důraz na souvislosti mezi výchovným působením a následným chováním. Větší pozornost je věnována samotnému vzdělávacímu procesu, který podporuje porozumění komplexním socioekologickým problémům a vede ke schopnosti je řešit, a to jak u jednotlivců, tak i v rámci společenství. Předpokladem takového vzdělávání je ovšem lepší pochopení kognitivních a emocionálních reakcí na určité environmentální téma. Tyto reakce jsou ovlivněny světonázorem a hodnotovým systémem každého člověka, a jsou tak spojeny s jeho identitou (Stevenson, Stirling, 2010). To znamená, že s ohledem na environmentální vzdělání se výzkum $v$ současné době zabývá především problémem, jak mohou lidé lépe pochopit vědecké poznatky o změně klimatu, přičemž se vychází z "kognitivní teorie ochrany identity". Z této teorie např́ílad vyplývá, že většina lidí je při vnímání klimatických změn ovlivněna svojí politickou příslušností a náboženským vyznáním (Kahan, Jenkins-Smith, Braman, 2011).

Zatímco přírodovědný výzkum se tradičně zabývá zkoumáním a pochopením prírodních procesů a jevů, které mají na svědomí environmentální problémy, výzkum v environmentálním vzdělávání se věnuje především zapojování veřejnosti do environmentálních témat (Bybee, 2010). To, že oba směry zkoumání je třeba propojit, rozpoznala Severoamerická asociace pro environmentální vzdělávání (NAAEE), která na této myšlence založila spolupráci s UnderwritersLaboratories - a spojila tak výzkum environmentálního vzdělávání a vědy s technologií, inženýrstvím a matematikou (E-STEM) (NAAEE, 2013). Mezi další témata, na která nyní při zkoumání problémů udržitelnosti klade důraz mnoho vědeckých kapacit $v$ oblasti přírodních věd, patří rozšíření oborového pohledu o mezioborové, integrující porozumění, nebo vytváření souvislostí mezi vědeckými informacemi a tradičními znalostmi, např́klad domorodými zkušenostmi a místně zakotvenými poznatky (Tytler, 2012). Znamená to, že ačkoliv se prírodovědné vzdělávání vyvíjelo odděleně od environmentálního, současný výzkum a vývoj v obou oblastech ukazuje na nutnost směřování $k$ interdisdciplinárnímu a přitom kontextově specifickému př́stupu, jehož výsledkem bude postupné propojování výzkumu ve vědě, vzdělávání a životním prostředí (Stevenson et al., 2013).

\section{Občanská věda (citizen science)}

Také nové vědecké směry popisované jako tzv. občanská věda (OV) otevírají četné možnosti zapojování veřejnosti do vědecké práce, a to např́íklad $v$ rámci spolupráce na řešení environmentálních problémů v lokálním měřítku (Shirk et al., 2012; Bonney et al., 2014). Dickinson et al. $v$ nedávném článku publikovali informaci, že hlavní možnosti této občanské vědy se otevírají v biologických studiích o globálních změnách klimatu (Dickinson et al., 2012). Autoři se shodují na tom, že výsledky občanské vědy a jí generovaná data mohou být nahlíženy jako veřejný statek, který může vzniknout pouze díky postupům a zdrojům stále více založeným na spolupráci. Považují zapojení veřejnosti do vědy za úhelný kámen toho, co nazývají "správcovství planety Země".

Občanská věda se nejčastěji uplatňuje $v$ oblasti komunitního monitoringu změn životního prostředí, přičemž se využívají jednoduchá zařízení ke sběru dat a přiměřené strategie pro komunikaci mezi zapojenými aktéry (vědci, občany). Nejnověji se $v$ této oblasti využívá internet, sociální média a mobilní aplikace pro získávání dat od velkého množství respondentů (Silvertown, 2009) - takže se postupně utvárí nová oblast občanské vědy využívající informační technologie (ICT supported citizen science). Tyto trendy jsou patrné i ve výzkumu v oblasti environmentálního vzdělávání, kde se ke sběru dat často využívají 
sociální média a/nebo pomoc občanů (kteří používají ICT) - to se pak považuje za způsob, jak zvýšit interakce mezi výzkumem ve vědě, ve vzdělávání a v životním prostředí (Stevenson et al., 2013).

\section{Souvislosti mezi EP, PP a OV}

Vytváření vztahů mezi environmentálním a přírodovědným vzděláváním například pomocí občanské vědy (př́ipadně využívající informační technologie) otevírá možnosti vzniku nových forem vzdělávání, které mohou vést $\mathrm{k}$ zapojení na první pohled nepř́buzných aktérů a organizací do tohoto procesu - ti pak generují nové poznatky a vyvíjejí aktivity nezbytné $\mathrm{k}$ řešení socioekologických problémů. Podobné synergie mohou být výsledkem takzvaného "celostního př́stupu v rámci školy" ("whole-school approach") k udržitelnosti a mohou se utvářet i v rámci alternativních způsobů výuky $v$ tzv. ekoškolách (jde např́iklad o badatelsky orientované vzdělávání, integrovanou oborovou výuku a sociální učení), a současně je možno využívat možností ICT, občanské vědy a spolupráce s místní komunitou (Hargreaves, 2008). Takto Ize např́klad proměnit školní pozemek v místo, kde se Ize učit o zdraví, potravinách, ekologických souvislostech atd. (to se děje na základě př́rodovědných poznatků) - a na druhé straně je možné využít environmentálního vzdělávání k posílení občanské angažovanosti a rozvíjení pocitu sounáležitosti s místem.

Například do zakládání tzv. „jedlých zahrad" („edible gardens") mohou školy zapojit různé sociální skupiny (místní zahradní centrum, restauraci, místní organizace a zastupitelstvo aj.), což zlepší kvalitu vzdělávání a zvýší jeho praktický dopad, přičemž se zároveň posílí vztah s místní komunitou (Ruiz-Gallardo, 2013). Příprava půdy, výběr semen, pěstování rostlin, jejich ošetřování, sklizeň a následná př́íprava jídel vyžaduje základní znalosti, které vycházejí z osnov prírodních věd, současně zde ale vzniká další přidaná hodnota spočívající $v$ zapojení místních obyvatel, zlepšení podmínek pro zdraví, zvýšení sebevědomí žáků a posílení jejich zakotvenosti $v$ místě (což je $v$ tomto případě založeno na souvislostech s pěstováním potravin) (Bell, Dyment, 2008).

Současný výzkum v oblasti environmentálního vzdělávání naznačuje, že využití občanské vědy v takovémto "hybridním" vzdělávání pomáhá žákům ovlivňovat kvalitu životního prostředí v jejich okolí (Stevenson et al., 2013). Tyto závěry potvrzují napríklad výsledky projektů YardMap financovaných U.S. National Science Foundation (Národním přirodovědným fondem Spojených států), což jsou projekty vědy se zapojením veřejnosti, které využívají ICT a ve výsledku nabízejí veřejnosti zajímavé zdroje informací o místním bohatství (mapový software). Současně tuto veřejnost ovšem zapojují do akcí na ochranu ptačích stanovišt $v$ daném místě.

\section{Místo a identita}

$\checkmark$ př́kladech sbližování přírodovědného a environmentálního vzdělávání, kde je současně využívána občanská věda, se zdůrazňuje sounáležitost $s$ místem a vztah $\mathrm{k}$ celé planetě Zemi. Tento důraz na místní identitu vychází z povahy současnosti: komplexnost a nejistota způsobená globalizací a rychlé tempo technologických a sociálních změn mají za následek podstatné kulturní změny, ale vedou i k pokusům o znovunalezení významu místa a vymezení jeho vztahu k místní identitě (Stevenson, Stirling, 2010). Často se soudí, že důvodem pro odcizování, ztrátu zakotvenosti v místě, je současná posedlost a závislost na informačních a komunikačních technologiích (Zaradic, 2008). Tento názor není dostatečně doložen; již nyní máme naopak důkazy o tom, že moderní technologie mohou lidi s místem 
znovu propojovat (Dickinson, et al., 2013). Existuje mnoho príkladů, kdy obyvatelé monitorovali svoje blízké prostředí (např. migraci ptáků, kvalitu vody, ovzduší, půdy), přičemž používali geografické informační systémy, mobilní telefony a speciálně navržené monitorovací aplikace (Bonney et al., 2014). ICT jako takové mají ve skutečnosti potenciál dostat lidi ven, do prírody, a to i ty, kteří tam obvykle nechodí. Pak i jejich zapojení do občanské vědy, kde se mohou podílet na výzkumu s využitím ICT, může prohloubit jejich vztah k místu, jehož jsou součástí, a také jim zprostředkovat porozumění tomu, jak současná věda funguje.

Společnost se musí naučit, jak se vypořádat s výzvami udržitelnosti. Na soustavném propojení environmentálního a prírodovědného vzdělávání - např́iklad v rámci občanské vědy zprostředkované informačními a komunikačními technologiemi - by mohly být založeny postupy, jak problémy udržitelnosti předkládat lidem. Autoři tohoto textu prosazují spolupráci mezi vědci, učiteli a veřejností, která by účinně propojila vědu se společností a současně vedla $k$ posilování místní identity; $k$ tomu by přispěla angažovanost veřejnosti a podpora procesů učení, jež mohou vyústit v přiznivé socioekologické dopady. Nové možnosti získávání a sdílení dat pomocí informačních a komunikačních technologií (ICT) mohou být využity $v$ environmentální vědě; zároveň je tak posilováno zapojování občanů do probíhajících debat o problémech místní a globální udržitelnosti a posilováno jejich povědomí o tom, co je potřeba udělat, aby bylo dosaženo pokroku $v$ této oblasti.

\section{Reference}

- Bell, A. C., \& Dyment, J. E. (2008). Grounds for health: the intersection of green school grounds and health-promoting schools. Environmental Education Research, 14(1), 77-90. http://dx.doi.org/10.1080/13504620701843426

- Bonney, R., Shirk, J. L., Phillips, T. B., Wiggins, A., Ballard, H. L., , Miller-Rushing, A. J., \& \& Parrish, J. K., (2014). Next Steps for Citizen Science. Science, 343(6178), 1436-1437. http://dx.doi.org/10.1126/science.1251554

- Bybee, R. W. (2010). What Is STEM Education?. Science, 329(5995), 996-996. http://dx.doi.org/doi:10.1126/science.1194998

- Dickinson, J. L., Crain, R. L., Reeve, H. K., \& Schuldt, J. P. (2013). Can evolutionary design of social networks make it easier to be "green"?. Trends in Ecology \& Evolution, 28(9), 561-569. http://dx.doi.org/10.1016/j.tree.2013.05.011

- Dickinson, J. L., Shirk, J., Bonter, D., Bonney, R., Crain, R. L., Martin, J., ... Purcell, K., (2012). The current state of citizen science as a tool for ecological research and public engagement. Frontiers in Ecology and the Environment, 10(6), 291-297. http://dx.doi.org/10.1890/110236

- Dillon, J., Brody, M., \& Stevenson, R, (2013). International handbook of research on environmental education. : Routledge.

- Gough, A. (2002). Mutualism: A different agenda for environmental and science education. International Journal of Science Education, 24(11), 1201-1215. http://dx.doi.org/10.1080/09500690210136611

- Hargreaves, L. G. (2008). The whole-school approach to eduation for sustainable development: From pilot projects to systemic change. Policy \& Practice - A 
Development Education Review, (6). : Policy \& Practice - A Development Education Review, (6). Dostupne z http://www. developmenteducationreview.com/issue6perspectives 2 . Retrieved from http://www.developmenteducationreview.com/issue6-perspectives2

- Kahan, D. M., Jenkins-Smith, H., \& Braman, D. (2011). Cultural cognition of scientific consensus. Journal of Risk Research, 14(2), 147-174. http://dx.doi.org/10.1080/13669877.2010.511246

- Kollmuss, A., \& Agyeman, J. (2002). Mind the Gap: Why do people act environmentally and what are the barriers to pro-environmental behavior? Environmental Education Research, 8(3), 239-260. http://dx.doi.org/10.1080/13504620220145401

- Naaee, (2013). E-STEM. . Retrieved from http://www.naaee.net/sites/default/files/ESTEM/ESTEM_NAAEE2013TearSheet.pdf

- Nisbet, M. C. (2009). Communicating Climate Change: Why Frames Matter for Public Engagement. Environment: Science and Policy for Sustainable Development, 51(2), 12-23. http://dx.doi.org/10.3200/ENVT.51.2.12-23

- Ruiz-Gallardo, J., Verde, A., \& Valdés, A. (2013). "Garden-Based Learning: An Experience With "At Risk" Secondary Education Students". The Journal of Environmental Education, 44(4), 252-270. http://dx.doi.org/10.1080/00958964.2013.786669

- Shirk, J. L., Ballard, H. L., Wilderman, C. C., Phillips, T., Wiggins, A., Jordan, R., . . . Bonney, R. (2012). Public Participation in Scientific Research: a Framework for Deliberate Design. Ecology and Society, 17(2), http://dx.doi.org/10.5751/ES$\underline{04705-170229}$

- Silvertown, J. (2009). A new dawn for citizen science. Trends in Ecology \& Evolution, 24(9), 467-471. http://dx.doi.org/10.1016/j.tree.2009.03.017

- Stevenson, R., \& Stirling, C. (2010) Environmental Learning and Agency in Diverse Educational and Cultural Contexts. In Robert B. Stevenson and Justin Dillon (Ed.), Engaging Environmental Education: Learning, Culture and Agency (pp. 219-238). Rotterdam: Sense Publishers.

- Tytler, R. (2012). Socio-Scientific Issues, Sustainability and Science Education. Research in Science Education, 42(1), 155-163. http://dx.doi.org/10.1007/s11165-011-9262-1

- Zaradic, P. (2008). Confronting Videophilia. Scientific American, 18(5), 24-24. http://dx.doi.org/10.1038/scientificamericanearth1208-24 